\title{
Empowerment, Deliberative Development, and Local-Level Politics in Indonesia: Participatory Projects as a Source of Countervailing Power
}

\author{
Christopher Gibson • Michael Woolcock
}

Published online: 5 June 2008

(C) Springer Science + Business Media, LLC 2008

\section{Erratum to: St Comp Int Dev (2008) 43:151-180 \\ DOI $10.1007 / \mathbf{s} 12116-008-9021-0$}

The original version of this article unfortunately contained a mistake. The second sentence in the Abstract was incorrect. The corrected data is given below.

Using evidence from a mixed methods examination of the Kecamatan (subdistrict) Development Project (KDP) in rural Indonesia, we define empowerment as development interventions that build marginalized groups' capacity to engage local-level governing elites using routines of deliberative contestation.

The online version of the original article can be found at http://dx.doi.org/10.1007/s12116-008-9021-0.

C. Gibson

Department of Sociology, Brown University, Box 1916, Providence RI 02912-1916, USA

e-mail: christopher_gibson@brown.edu

M. Woolcock ( $\square)$

Brooks World Poverty Institute, University of Manchester, Bridgeford Street Humanities Building,

Oxford Road, Manchester M13 9PL, UK

e-mail: michael.woolcock@manchester.ac.uk 